特集 バイオテクノロジーと水処理技術 水処理におけるニューバイオテクノロジー研究開発の現況 遺伝子工学の水処理への応用

\title{
Present aspects for the Research Developments of New Biotechnology in Water and waste Trcatment
}

橋本奨*

緒 言

一昨年度から用廃水処理へのバイオテクノロジー活 用の気運が高まり, 民間活力導入ということで, 昨年 度から建設省では「バイオフォーカスWT計画」や通 産省では「アクアルネッサンス計画」という国レベル の官産学の研究活動が始動されるようになり, 今年は 2 年目を迎え, 誠に喜ばしいことである.

これまで, 筆者橋本と藤田 ${ }^{1)}$ は,「分子育種技術の 廃水処理への応用一遺伝子工学からの視点一」という テーマで, 水処理における研究開発の動向を紹介した ことがある.乙こでは, 水処理におけるバイオテクノ ロジー, 特に遺伝子工学の活用について筆者の目にと まったその後の研究開発の現況を紹介する.

1. バイオテクノロジーとは2,3)

バイオテクノロジーとは, 用語そのものから，また より広くとらえると, “生物工学”ゃ “微生物工学” あ るいは “生物や微生物の利用技術” の乙とで, 生物や 微生物またはそれらの一部の機能を，図一にに示したよ うに，制御あるいは利用することにより，われわれの
生活を豊かにし，また健康の維持増進をはかる技術で， われわれのまわりの環境の生態系バランスを目標とせ ねばならないてとはいうまであない。てれまで下・排 水の処理では, 都市や地域の環境, とくに水環境の生 態系バランスの維持, 保全のため, 古くから活性污泥 法や生物膜沪床法, 嫌気消化法, 酸化池法等, 多種多 様の生物（細菌, 原生動物, 後生動物等）の混合培養 系を用いて処理されてきたので, 古い形のバイオテクノ ロジー(生物工学)は, 極めて効果的に活用されてきたとい うことである. しかし, 最近の微生物利用工業では, 図-2 で示したように, 遺伝子組み換え, 細胞の融合や接合, ま た酵素や微生物の固定化技術の応用か榌躍的に進展し, その成果があまりにあ華やかに宣伝されたため, 現在この 技術が即二ュウーバイオテクノロジーとみられているもので ある. また, この技術の利用は, 図示したように, 遺伝子の 情報伝達に関する基礎研究から創造されたものである から，乙てで扱う生物種はすべて図-3のようにして, 特殊機能をむつ高性能変異株を分離してから, ての単 一純粋微生物細胞を使用することになるので，下・排 水の生物処理におけるような食う食われるの複雑な食 物連鎖の生態系を構成する混合培養系とは，著しく趣

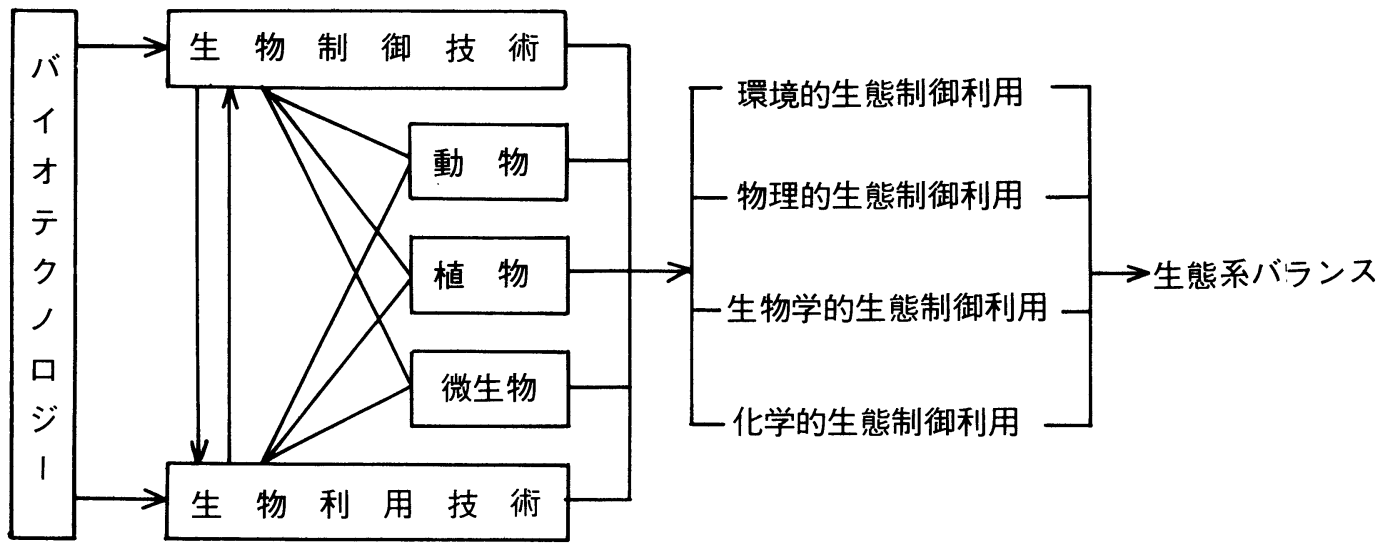

* 大阪大学工学部環境工学科教授

図-1 バイオテクノロジーと生態バランス

Susumu HASHIMOTO 


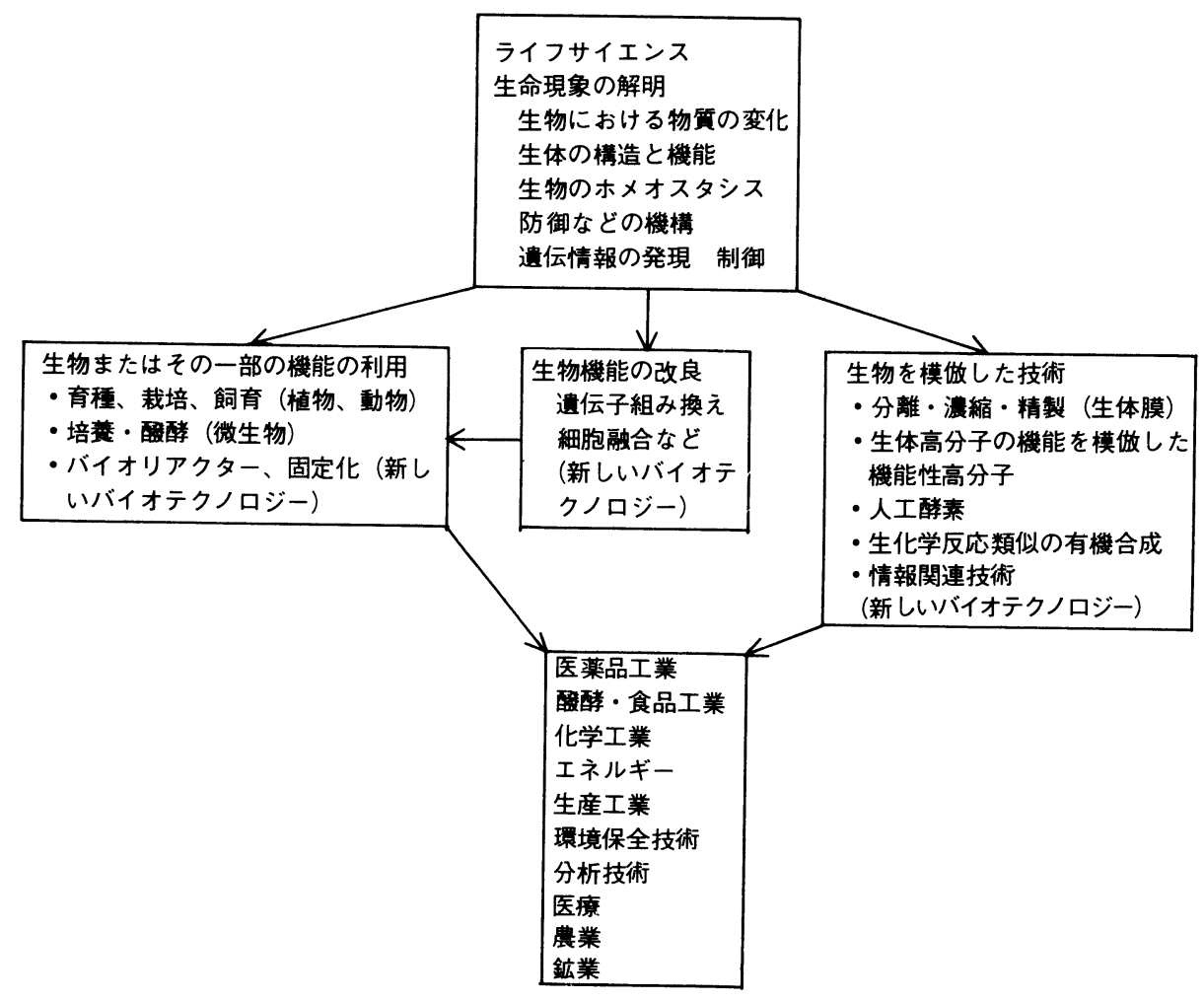

図-2 バイオテクノロジーの基本概念

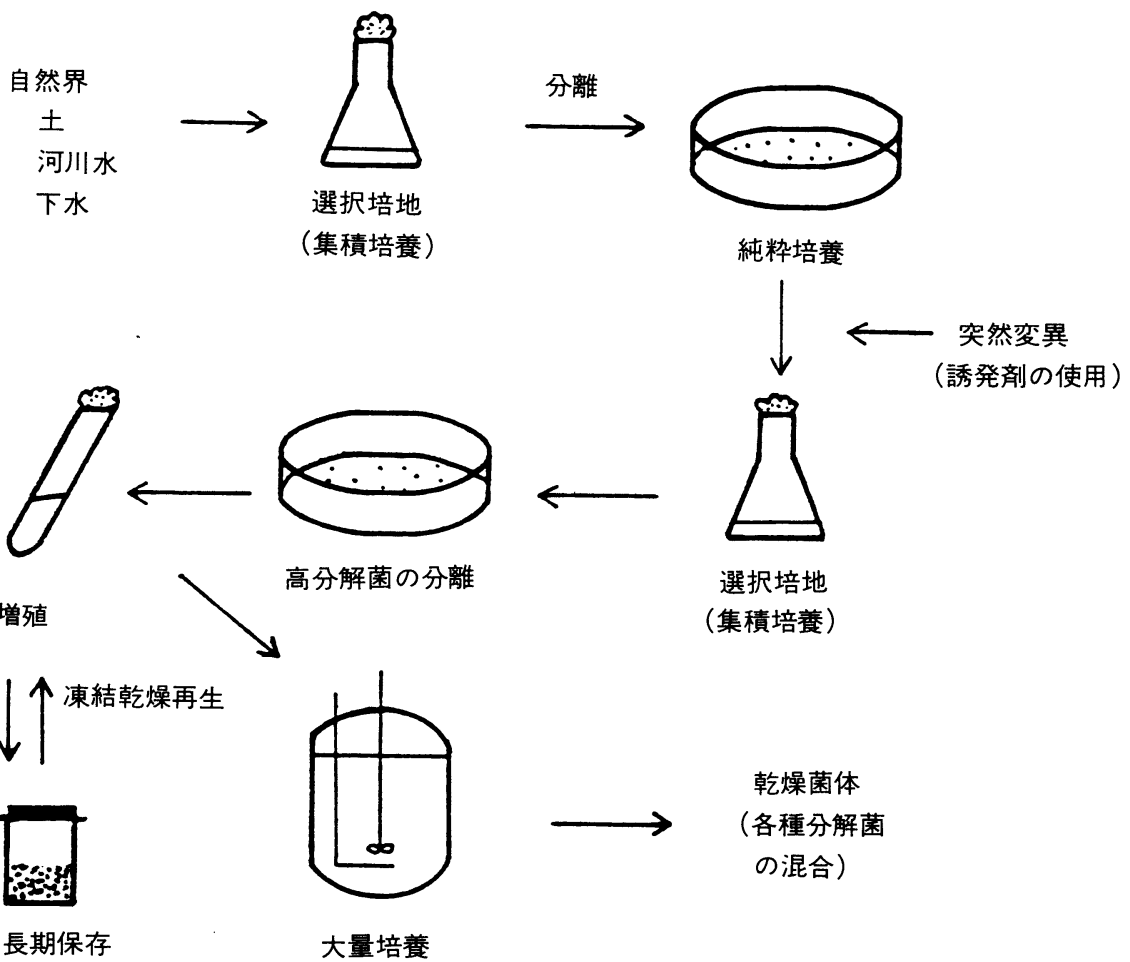

図-3 高性能変異株の分離操作 
を異にしているあのである. 従って, ての新しいバイ オテクノロジーは，乙れまで水処理分野へ活用された ことは全くなく，乙れの活用は遺伝子組み換えや 細胞融合, 接合等の分子育種技術を駱使して, 水処理 微生物の機能の改良により, 処理機能を飛躍的に增大 させようとする，てれまでになかった画期的な試みな のである.

\section{2. 水処理とニュウーバイオテクノロジー2,3)}

現在の水処理技術は, 稀薄な污染水を安価, 迅速, 大量に処理しょうとする条件を満足させるためには, 将来共に微生物を主体として利用せね将ならないとい うことは誰しあ異論のないとてろである。それという のも, 微生物は, (1)単位生体当りの污染物の分解或は 摄取速度が大きい. (2)比增殖速度が著しく大きい. (3) 自動触媒的に増殖する. (4)微生物は無限に存在する. 等の他の生物に比べて有利な点が多いからである。

従って, 遺伝子工学技術の水処理技術への応用とは 主として有用微生物の育種ととらえることができる. ててで, 育種の目的として, 次のようなあのがあげら れる.

1. 微生物当りの酵素生産 (分解速度) を増大させる.

2. 増殖速度を増大させる (悪環境下であ増殖する).

3. 多機能性微生物を作る.

4. 毒物耐性微生物を作る.

5. 凝集・沈降性（分離性）をよくする.

等である.

即ち, 従来の活性污泥等の水処理微生物群が, 個々 に持っていた多くの機能を, 一種類でできるだけ多く あった微生物を育種するととを目的とする.

こてで, 下水道や下・排水の生物処理に役立つ特殊 な機能をあつ微生物として, (1)フロっク形成細菌, (2)
生物膜付着促進細菌, (3)バイオポリマー生産菌, (4) 難 分解性物質分解菌, (5)硝化菌, (6)脱窒細菌, (7) リン蓄 積細菌, 8)重金属リーチング細菌（重金属含有污泥か らの重金属溶出に働き, 污泥の有効利用に役立つ), (9)重金属蓄積細菌, (10)悪臭分解細菌, (11)毒物分解細菌, (12) 低 $\mathrm{pH}$, 低温度, 低酸素, 低有機物濃度の各有機物 分解細菌, (13)嫌気性有機物分解酸生成細菌, (14) メタン 生成菌, (15)光合成細菌, (16)藻類や原生動物一等, 種 々の微生物を考えることができる，現に，難分解生物 質であるフェノール分解菌やポリビニルアルコール分 解菌等は, 実用化されている。自然界には，PCBや BHC, DDT, ABSなどその他多くの難分解性と いわれる物質を分解する細菌が抢り，すでにかなり以 前からこれら一部の細菌は純粋分離され，下・排水の 処理に活用しょうとする研究が進められ, 現に利用さ れている.乙れら微生物株は, 極めて貴重な遺伝情報 をむつ微生物資源で, ニュウーバイオテクノロジーを 用いると, 各種方面に活用でき, 現在は微生物銀行も つくられている時代なのである.

\section{3. 水処理生物とニュウーバイオテクノロジー2,31}

生態学の多様性原理によれば，生態系に抢ける種の 多様性の価値はその系の安定性の増加にあり, 系の環 境適応の可能性はそてにいる生物種が多ければ多いほ ど，適応のポテンシャルは大きくなるといわれる．上 水や下水, 排水の生物処理では, その系は多種多様の 生物種からなる自然生態系であるから，新しいバイオ テクノロジーで用いる単一純粋系よりもその系の安定 性は極めて高いものである，単一純粋系の特殊な機能 を強力にもつ特定細菌を分離し, 図-4のようにして育 種し，上，下・排水や污泥の処理に活用しようとする 場合には，それが複雑な食物連鎖をすつ自然生態系に

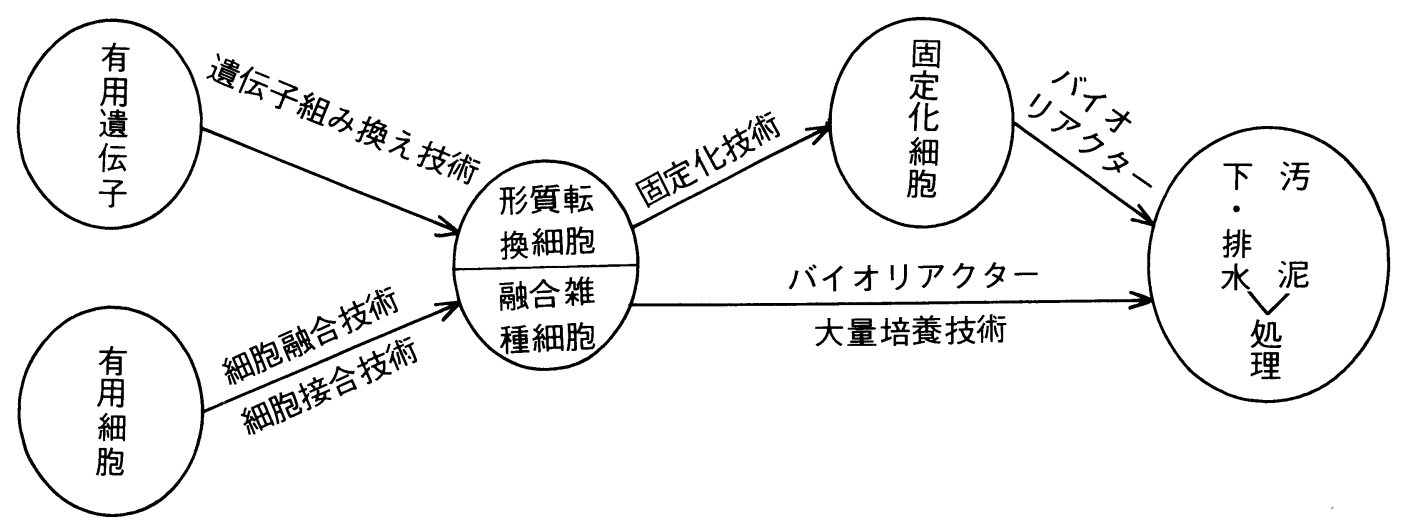

図-4 下・排水・污泥処理に抢けるバイオテクノロジーの活用 


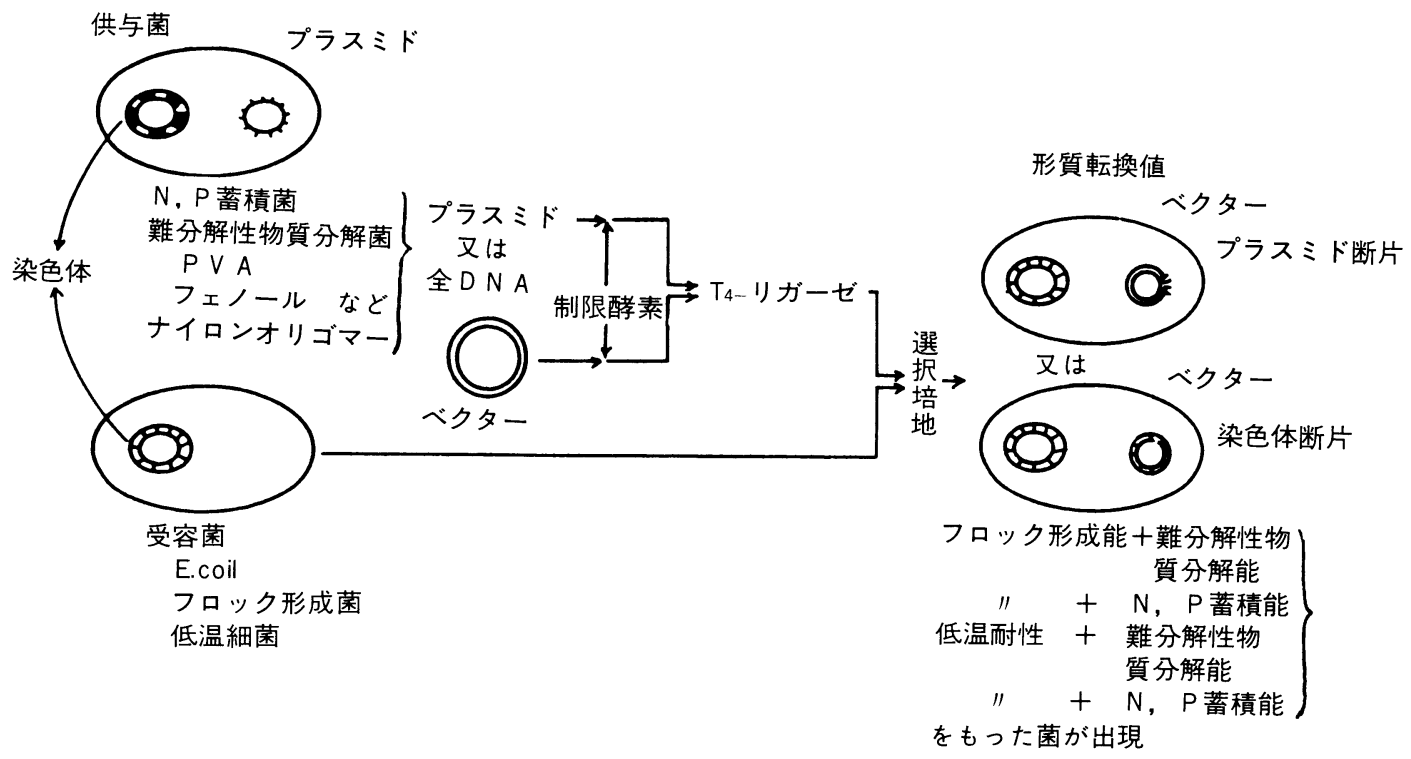

図-5 形質転換法による育種モデル

近い水処理生物の系の中でどのように機能するかは, 現在のとてろ不明のてとが極めて多い，従ってての解 明は, 二ユウーバイオテクノロジーの水処理技術への 活用のために極めて重要な研究課題になるはずである.

一般に, 好気環境の好気生物処理では, 有機物, 細 菌, 原生動物の間の食う食われるの働きで, また, 嫌 気環境の嫌気生物処理では, 拮抗や共生状態下の多く の細菌による有機物分解からの生成有機酸のガス化の 働きで, それぞれ浄化処理が機能するあので, 特に前 者では, 原生動物による細菌捕食が重要な鍵を担って いるあのである. 従って, たとえ特殊の機能を強力に あつ細菌を分離して活性污泥や嫌気消化污泥等にてれ を加えて活用, 企図しても, 乙の細菌の増殖速度之原 生動物の増殖速度或は拮抗細菌等の増殖速度をうまく 調和させない限り，うまく作動しないあのである。一 般に特殊機能をむつ細菌の増殖速度は極めて遅い. こ
の細菌の特殊機能を担うプラスミド (染色体外因子)遺伝 子を, 新しいバイオテクノロジーの遺伝子組み換え（図 -5）と細胞融合（図-6）や接合（図-7）等の技術を用 いて増殖速度の速い処理活用細菌の細胞内に入れ込ん で, 種々な特殊な機能をむつ細菌を育種して, 生物処理 系の中で原生動物或は拮抗細菌等の増殖速度とうまく 調和させて浄化処理に活用することは, 将来性と可能 性のある課題である. また, 特殊な機能をもつ細菌を 原生動物の捕食や他の細菌や微生物の拮抗から守るた めに, この細菌を, 新しいバイオテクノロジーの固定化技 術(図-8, 図-9)を用いて固定化材内に閉じ込め, 乙れを 生物処理系の中で特殊な機能を働かせることも十分可 能なととである。

これまで微生物の固定化材として, ポリアクリルアミド, $\kappa$-カラギーナン, アルギン酸カルシウム, 光硬化性樹脂等が 用いられ, 微生物工業では, 実用化されているが, 水処

フロック形成菌

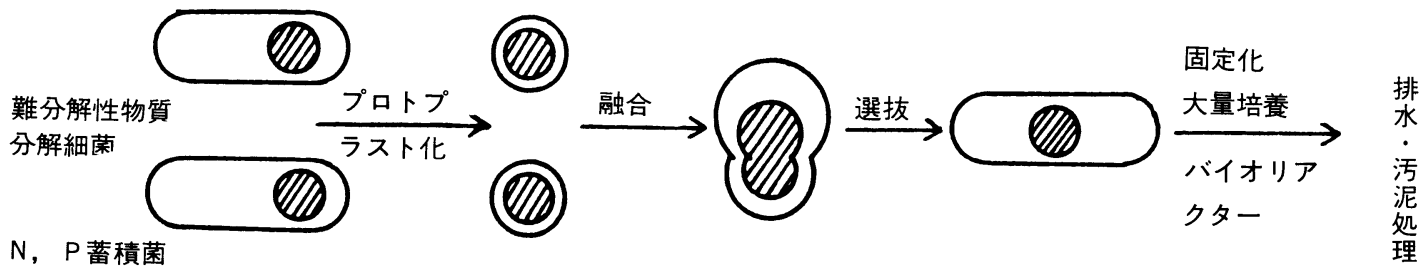

2 種の有用細菌

プロトプラス

細胞融合

雑種細胞

図-6 細胞融合法による育種モデル

注）現在のとてろ, グラム陽性菌でのみ成功している. 

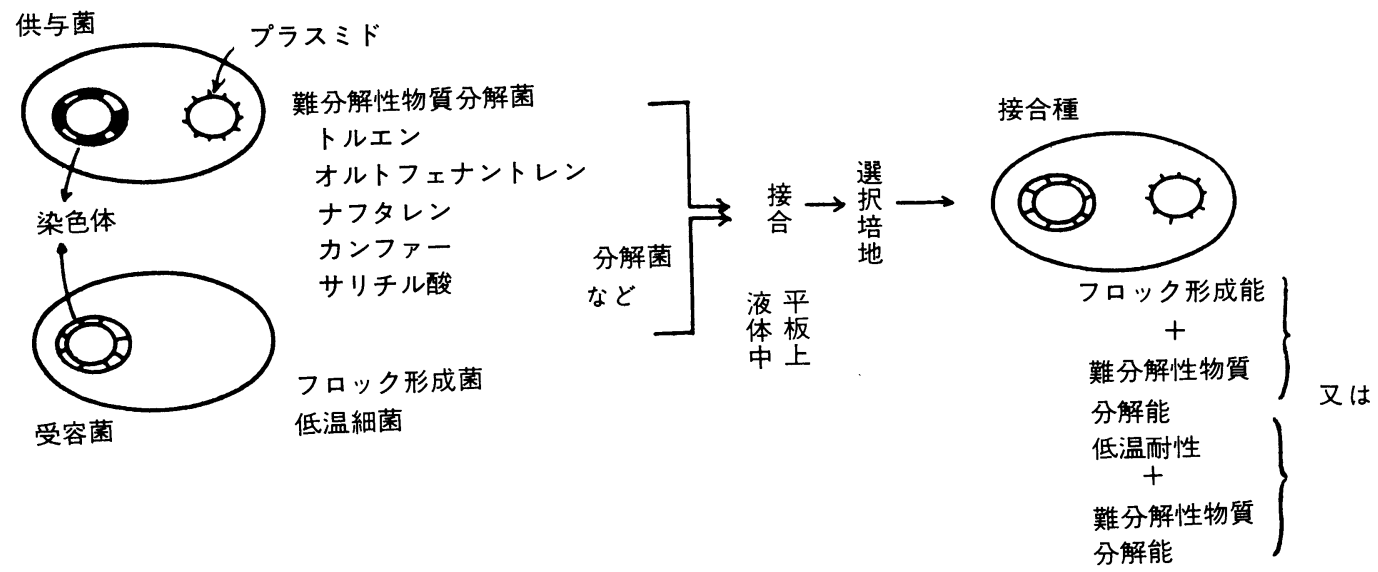

図-7＼cjkstart接合法による育種モデル

理に使うには今のとてろあまりにあ高価で，また，一 部アクリルアミドのように微生物傽害を与えるむの ああるので, 安価で強固な, また微生物に対して毒性 の少ない他の固定化材の検索が望まれる，筆者らは， PVA（ポリビニルアルコール）之硼酸を用いて, 安価 かつ強固で，毒性もほとんどなく，長期にわたって使 用に耐えるPVA-硼酸法 ${ }^{2}, 31$ による固定化材を開発し， 現在その実用化試験を行っている。

\section{4. 水処理のための遗伝子工学研究開発の現況}

てれまで, Chakrabarty等の研究1,4)などで代表さ れるように，育種微生物の環境净化または水処理への 応用では, あくまで研究の本筋はもう少し基礎的な面 にあり, それらの研究成果が水処理分野へ応用可能で はないかということで発展してきたといえる，従っ て作られた微生物は必ずしあ現在の水処理技術にマッ チしたあのとは言えない，あちろん，てのようにして 得られた育種微生物に合わせた水処理技術が開発され るかも知れないが….... 水処理技術にマッチした微生 物之は, 現在の所, (1)フロック形成能, (2)生物膜付着 促進能, (3)広範囲 $\mathrm{pH}$, 低温, 低酸素, 低有機物濃度 などの悪環境耐性能等の性質を有し，かつ難分解性物 質分解能などの他の多くの機能を併せ持った微生物と 言えるのではなかろうか。

以上の点を考慮すれば, 微生物育種の受容菌として フロック形成菌がクローズアップされる，乙れに，他 の機能を持たせることができれば，理想的な水処理微 生物へ一歩近づいたと言える。しかし，乙の方面で の研究は極めて少なく, 多胡ら ${ }^{51}$ の研究があるのみで
ある，乙の研究とは逆に，フロック形成の一要因にな ると考えられるアルギン酸（バイオポリマー）生産遺 伝子を操作した例が報告されている れば，例えば難分解性物質分解菌にフロック形成能を 持たせることも可能である。

難分解性物質分解菌の遺伝子またはプラスミドに関 する研究は，近年その数を増してきた．3ークロロ安息 香酸，4-ク口ロ安息香酸，3，5 - ジクロロ安息香酸, 2，4-ジクロロビフェニルなどの有機八ロゲン化合物 の分解系プラスミドについては, 外村, 川崎7が詳し く報告している。報告されたプラスミドの分子量は一 般汇大きく50Mdal (メガダルトン) 程度で, 伝達性 のあるものが多い。また焼却の是否で問題となってい るポリ塩化ビフェニル ( P C B ) 分解プラスミドも通産 省微生物工業技術研究所により発見された。

一方, 矢野らのグループ8, 9) は, アルキルベンゼン 類分解系プラスミドに関する一連の研究を通じ,メチ ルベンゼン (トルエン) 及びェチルベンゼン分解プラ スミドを見付け，さらに $\mathrm{n}$-ドデシルベンゼンなどの分 解菌についてあ現在検討されつつある.

水銀耐性については, Robinson \& Tuovinen ${ }^{10}$ 'は, 図一10のモデルを提案し，水銀耐性菌は酵素的に $\mathrm{Hg}^{2+}$ $\rightarrow \mathrm{Hg}^{0}$ とし, $\mathrm{Hg}^{2+}$ イオンに耐性を作ると共に, $\mathrm{Hg}^{0}$ を 系から揮散させるととを示した。一方, Chakrabarty ${ }^{111}$ あ，水銀耐性プラスミドについて報告している。その 他の $\mathrm{Cd}, \mathrm{Zn}$ などの有害重金属イオンを無害化したり, 蓄積したりする細菌は，自然界には多数分布している。

Shoda et $a 1^{13)}$ は, 自然界より燐蓄積細菌Arthrobacter globiforms PAB-6を分離し, 平石ら ${ }^{13)}$ は, 


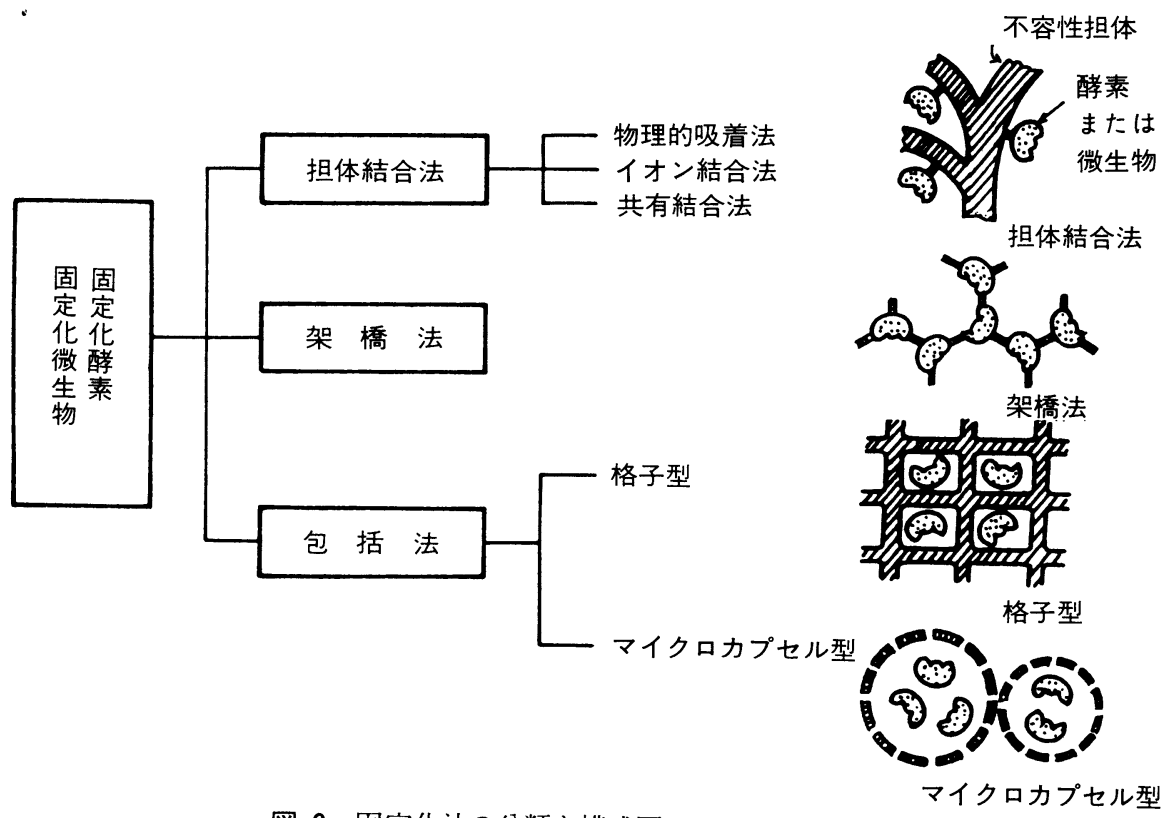

図-8＼cjkstart固定化法の分類と模式図

光合成細菌Rhodopseudomonas（Rhodobacter と 名前を替えた）sphaeroidesが高濃度の燐を蓄積する ことを報告した。しかし，その遺伝的性質については 不明である。

今井 ${ }^{14)}$ は, バクテリアリーチングの中心をなす鉄酸化細 菌のプラスミドについて解説し, 発見されたプラスミ ドが亜ヒ酸耐性に関与しているととを示唆すると共に, てれらのプラスミドを利用して組換え DNA 用ベクタ 一の開発が可能なととを予想している。しかし，プラ スミドの役割についてはほとんど不明であり,やっと研 究が始まった所と言える.ただ,Rawlings \& Woods ${ }^{15}$ )
は，遺伝子操作への 1 つの試みとして Thiobacillus ferrooxidansのプラスミドを制限酵素まで切ってpBR 325にクローニングし，てれをE. coli間で接合伝達さ せ, 成功している。

硝化, 脱窒細菌, 悪臭分解菌などに関する報告は極 めて多いが，その遺伝的解析はてれからである.

光合成細菌は, 污水処理や水素生産などに用いられ ているが, 遺伝的性質についての研究はてれからであ る. この一例として, 梶原ら ${ }^{(6)}$ は, 水素生産株の育種 を目的とし, Rhodopseudomonas と Sphaeroides の二株の細胞融合を行い, 成功している.

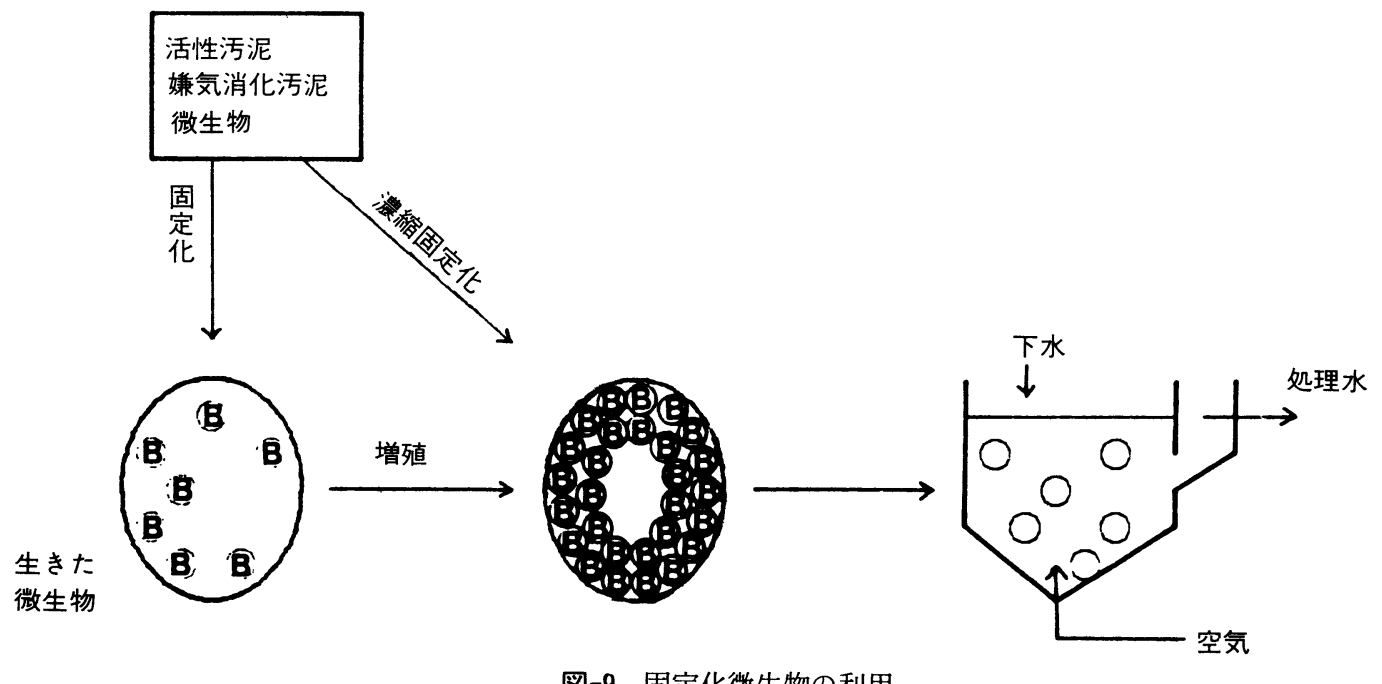

図-9 固定化微生物の利用 


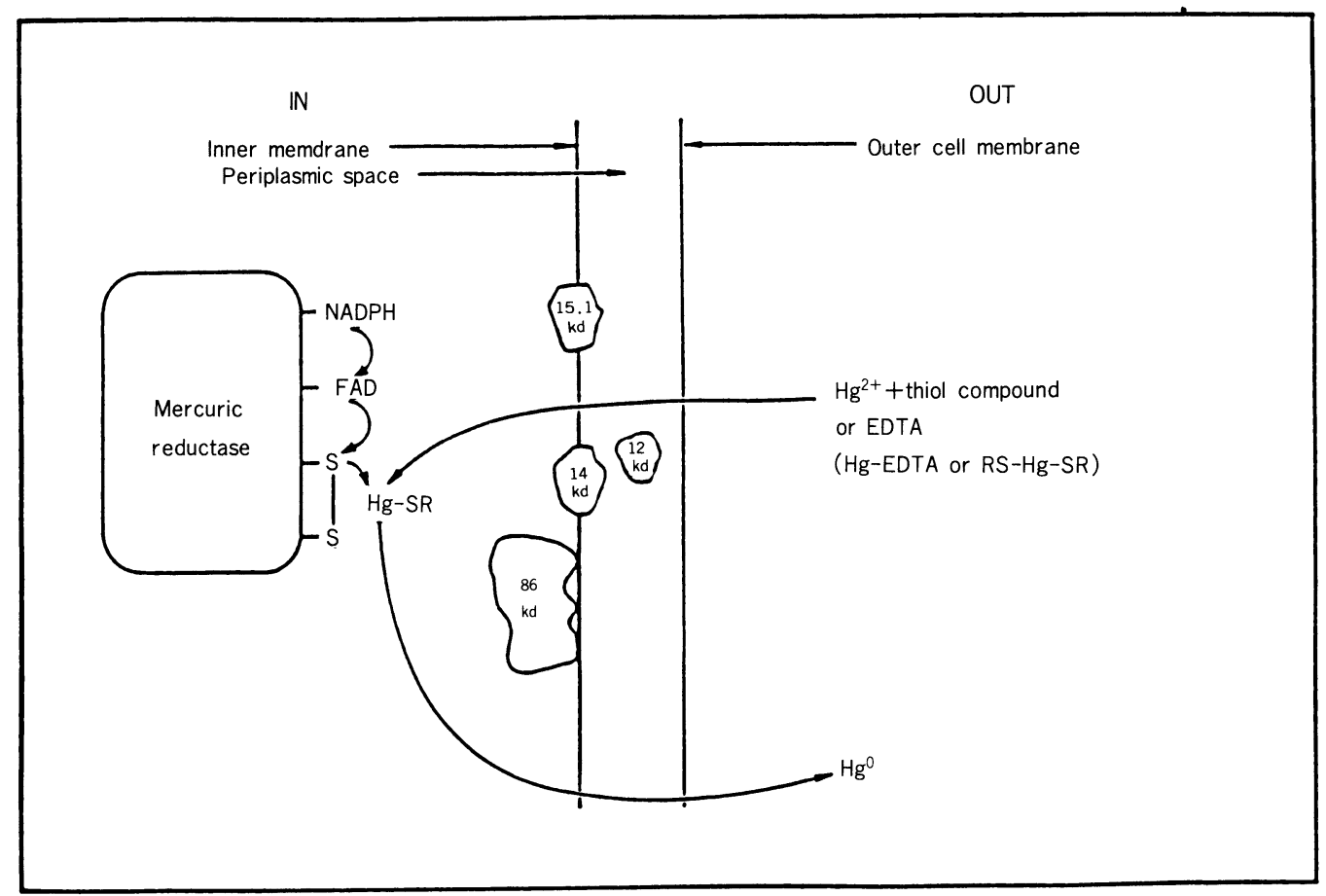

図-10 プラミドR 100 に支配された水銀還元酵素による $\mathrm{Hg}^{2+}$ イオンの還元と水銀耐性メカニズム

各種機能を持った遺伝子が受容菌中に落ち着いた場合, 次のステップとしててれら遺伝子の機能強化即ち, 酵 素の多量生産が考えられる.乙れには, lac UY5 プロ モーターなどのように，遺伝子の読み取り頻度を上げ

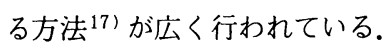

最後に, 自然的遺伝子改良の例として, Chakrabarty ${ }^{18)}$ が提唱したplasmid-assisted molecular breeding（プラスミド支援分子育種法）を以下に示す.そ の方法は，てれまで述べてきたてとからも理解される ように, 自然界ではプラスミド上の遺伝子の組み換え が頻繁に行われ, 乙れに遺伝子の変異, 進化が加わっ て, 全く新しい機能をもったプラスミドが出現してく る現象に着目して, てれを積極的に実験室でおし進め るととにより, より強力な分解菌を短期間に育成しよ うとするあのである.

この方法の実例として, Chakrabarty は, 2, 4, 5-トリクロロフェノオキシ酢酸 (2, 4, 5-T)分解菌 を次のようにして得ている. 化学薬品廃棄場の土裹試 料に, CAM, SAL, TOL, pAC21, pAC25なよ゙のプ ラスミド保有菌を加え, ケモスタットを用いて, 最初 はそれぞれのプラスミドの基質と少量の2, 4, 5-T を 炭素源とし, その後, 次第に $2,4,5$-Tの濃度を上げ てゆき, 約 6 ケ月後には完全に炭素源を $2,4,5-\mathrm{T}$ に
置き換えて培養したところ，2，4，5-T を単一の炭素 源として生育する強力な分解菌が得られた。乙の株は 1 週間で $1.5 \mathrm{mg} / \mathrm{m} \ell の ~ 2,4,5-\mathrm{T}$ を90\%以上分解した。 対照として, 土壌試料だけを同じように培養したもの からは，乙のような分解菌は出ててなかった. 2, 4, 5 一个は除草剂として使われているが, 非常に難分解性 で, 完全分解する菌株はまだ自然界から分離されてい なかった。乙の方法は単に分解菌の育種法としてだけ でなく, 種々の有用細菌の分子育種法として, 今後広 く利用されるように思われる。

\section{結語}

現在, 遺伝子工学, つまり微生物の接合から形質転 換までの遺伝子移動による分子育種技術を用いて，目 的とする微生物を計画的に作りだすととが可能になっ ている. 水処理におけるニュウーバイオテクノロジーの意義 と価值を概説しながら, 最近の目につく水処理のための遺 伝子工学研究開発の現況を述べた. 新しいバイオテクノロ ジ一の水処理技術への活用のための基礎研究の課題は 山積みの状態で, 従って水処理分野のより多くの研究 者が今後ての分野へ参入されるてとを念じるとともに この分野の活発な討議と発展を期待して本稿を終えた w. 
文

\section{献}

1) 橋本奖, 藤田正憲: 分子育種技術の廃水処理への応用一 遺伝子工学加らの視点一, 水処理技術, Vol 24, No. 9,. $13 \sim 29$ (1983).

2 ）橋本觉: バイオテクノロジーと下水道, 建設月報, No.432, 6 月号, 61〜68 (1985).

橋本奖: バイオテク/ロジーとは一下水生物処理から の視点一, 月刊下水道, Vol. 8, N0. 8, 2〜8 (1985).

3 ）橋本奖: 下廃水処理におけるバイオテクノロジーの概観 之展望, 用水之廃水, Vol. 27, No.11, 3〜13 (1985).

4 ) Chakrabarty, A. M., Chou, G., Gunsalus, I. C.: Genetic Regulation of Octane Dissimilation in Pseudomonas, Proc. Nat. Acad. Sci., U. S. A., Vol. 70 (4), p1137 $\sim 1140$ (1973).

5 ) Tago, Y., Oishi, K., Yano, K., Aida, K.:“Transfer of T OL Plasmid to a Floc-Forming Bacterium, Pseudomonas sp. No.12", 4 th Int Symp. on Genetic of Industrial Microorganisms, June 6-11, Kyoto (1982).

6 ) Goldberg, J. B., Ohman, D. E. : “Cloning and Expression in Pseudomonas aeruginosa of a Gene Involved in the Production of Alginate", J. Bact., Vol. 158, pp. 1115 1121 (1984).

7 ）外村, 川崎: “細菌による有機ハロゲン化合物の分解之 プラスミド，蛋白質，核酸，酵素、Vol. 29, pp. 111〜 126 (1984).

8 ）金光, 西, 矢野: “Pseudomonas属における新プラスミ ドの検索: アルキルベンゼン類分解系プラスミドの単離” 昭和59年度日農化大会, 予講集, p. 172 (1984).

9 ) 西, 福田, 矢野: “污染物質分解細菌の質的改良:多資化 性Pseudomonas の分離とそのプラスミド”，昭和 59 年 度日農化大会, 予講集, p. 172 (1984).
10) Robinson, J. B., Tuovinen, O. H.: “Mechamisms of Microbial Resistance and Detoxification of Mercury and Organomercury Compounds: Physiological, Biochemical and Genetic Analyses", Microbiological Reviews, Vol. 48, pp. 95 124 (1984).

11) Chakrabarty, A. M.: "Plasmids in Pseudomonas", Ann. Rev. Genet, Vol.10, pp. $7 \sim 30$ (1976).

12) Shoda, M., Ohsumi, T., Udaka, S.: "Screening for High Phosphate Accumulating Bacteria," Agr. Biol Chem., Vol. 44 (2), pp. 319 324 (1980).

13) Hiraishi, A., Kitamura, H.: J. Ferment. Technd., Vol. 62, p. 293〜296 (1984).

14）今井:“バイオハイドロメタラージーの展望”, BIO IN DUSTRY, Vol. 2 (9), pp.709〜 716 (1985).

15) Rawlings, D. E. \& Woods, D. R.: "Mobilization of Thiobacillus ferrooxidans Plasmids among E. coli. Strains", Appl. Environment. Microbiol., Vol. 49, pp. 1323 1325 - 1985).

16）梶谷, 中島, 民谷, 軽部: “光合成細菌の細胞融合”, 昭 和60年度醴酵工学大会講演要旨集, p. 24 (1985).

17）岡田, 根来, 木下: “非天然物質ナイロンオリゴマー分 解系酵素之その遗伝情報”，蛋白質，核酸，酵素，Vol. 27， pp. $451 \sim 465$ (1982).

18) Kellogg, S. T., Chatterjee D. K., Chakrabarty, A. M. :"Plasmid-Assisted Molecuar Breeding: New Technique for Enhanced Biodegradation of Persistent Toxic Chemicals", Science, Vol. 214, pp. 1133 1135 (1981). 